\title{
Always Steering a Straight Course? The German Federal Constitutional Court and European Integration
}

\author{
Torsten Stein
}

(C) ERA 2011

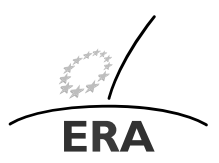

EUROPÄISCHE RECHTSAKADEMIE ACADEMY OF EUROPEAN LAW ACADEMIE DE DROIT EUROPEEN ACCADEMIA DI DIRITTO EUROPEO

TRIER - TREVES - TREVIRI

\begin{abstract}
In the early years of European Integration the German Federal Constitutional Court seemed to be very willing to support the European Court of Justice in its decisions to push integration forward. Later on the Constitutional Court claimed a residual competence to control the protection of human rights and to declare ultra virus acts of Community organs as inapplicable in Germany. No action ever followed those strong words, and with its latest decision in Honeywell the Constitutional Court returned to its original position.
\end{abstract}

Keywords German Federal Constitutional Court · European Court of Justice · Protection of human rights · Ultra virus acts

\section{Introduction}

Ships normally steer a straight course, unless they try to escape from pirate attacks off the coast of Somalia. The course steered by the German Federal Constitutional Court vis-à-vis the European Integration at times appeared to be a bit erratic, at least verbally. Among the Constitutional Court's responsibilities are the protection of human (fundamental) rights, the protection of the prerogatives and the sovereignty of the German legislative bodies, and, most recently, of the "constitutional identity". At times one could get the impression that the Constitutional Court felt the need to escape from or defend against attacks from Europe on these cornerstones of German statehood. But in the end, as we will see, the Court found back to its original course; maybe even a bit too easily.

Professor Dr. T. Stein, Chair for European Law and European Public Law, Director of the Europa-Institut $(\varangle)$

University of Saarland, Saarbruecken, Germany

e-mail: t.stein@mx.uni-saarland.de 


\section{The Early Years}

Soon after the leading decisions of the European Court of Justice (ECJ) in Van Gend \& Loos and Costa v. ENEL, ${ }^{1}$ in which it described the EEC-Treaty as establishing an autonomous legal order, taking precedence over the legal orders of the Member States and having (in part) direct effect, the German Constitutional Court followed ${ }^{2}$ by saying that the EEC was a "new" public power, independent of the power of the Member States, not a state or federal state, but a sui generis community in the process of progressive integration. Legal rules adopted under their competences were neither public international nor national law.

In 1971, the German Constitutional Court found a basis in the German Basic Law (Constitution) for adopting the ECJ's position, ${ }^{3}$ finding that Article 24 of the Basic Law (the then "integration article"), if properly interpreted, would not only allow the transfer of sovereign powers to international organisations, but would also mandate that legal acts of such organisations had to be acknowledged and implemented.

Even many years later, the Constitutional Court showed itself rather generous in accepting a sometimes quite "dynamic" interpretation of Community law by the ECJ, when it declared the "direct applicability" of EC directives as being still covered by the "integration programme". 4

But in the meantime, in 1974, came a first warning shot.

\subsection{The "Solange I" Decision}

On 29 May 1974, the German Constitutional Court ruled in an export license case, that had previously been referred by a German Administrative Court to the ECJ (which had confirmed the legality of the disputed EEC Regulation) and had then - because the Administrative Court disliked the ECJ's answer - been referred again to the Constitutional Court. To the surprise of many, the Constitutional Court decided, although not finding any illegality in the given case: "As long as the integration process has not progressed so far that Community law receives a catalogue of fundamental rights decided on by a Parliament and of settled validity, which is adequate in comparison with the catalogue of fundamental rights contained in the Basic Law, a reference by a court of the Federal Republic of Germany to the Federal Constitutional Court in judicial review proceedings, following the obtaining of a ruling of the European Court under Article 177 of the Treaty (now Article 267 TFEU), is admissible and necessary if the German court regards the rule of Community law which is relevant to its decision as inapplicable in the interpretation given by the European Court, because and in so far as it conflicts with one of the fundamental rights of the Basic Law".

The Constitutional Court explained its decision as follows:

\footnotetext{
${ }^{1}$ Case 26/62 Van Gend \& Loos [1963] ECR 1 and Case 6/64 Costa v. ENEL [1964] ECR 1251.

${ }^{2}$ BVerfGE 22, 293.

${ }^{3}$ BVerfGE 31, 145.

${ }^{4}$ BVerfGE 75, 223.

${ }^{5}$ BVerfGE 37, 271.
} 
“... it is not enough simply to speak of the "precedence" of Community law over national constitutional law in order to justify the conclusion that Community law must always prevail over national constitutional law because, otherwise, the Community would be put in question. Community law is just as little put in question when, exceptionally, Community law is not permitted to prevail over cogent ("zwingendes") constitutional law, as international law is put in question by Article 25 of the Basic Law when it provides that the general rules of international law only take precedence over simple federal law (...). The binding of the Federal Republic of Germany (and of all member states) by the Treaty is not, according to the meaning and spirit of the Treaties, one-sided, but also binds the Community which they establish to carry out its part in order to resolve the conflict here assumed, that is, to seek a system which is compatible with an entrenched precept of the constitutional law of the Federal Republic of Germany. Invoking such a conflict is, therefore, not in itself a violation of the Treaty, but sets in motion inside the European organs the Treaty mechanism which resolves the conflict on a political level (...).

Article 24 of the Basic Law deals with the transfer of sovereign rights to interstate the institutions. This cannot be taken literally. Like every constitutional provision of a similar fundamental nature, Article 24 of the Basic Law must be understood and construed in the overall context of the whole Basic Law. That is, it does not open the way to amending the basic structure of the Basic Law, which forms the basis of its identity, without a formal amendment to the Basic Law, that is it does not open any such way through the legislation of the interstate institution (...). The part of the Basic Law dealing with fundamental rights is an inalienable, essential feature of the valid Basic Law of the Federal Republic of Germany and one which forms part of the constitutional structure of the Basic Law".

Twelve years later the Constitutional Court, after having given some more or less open indications in this respect in decisions not relating to Community Law, ${ }^{6}$ completely reversed the "Solange I" formula.

\subsection{The "Solange II" Decision}

On 22 October 1986, the Constitutional Court ruled in a case which had factual and procedural backgrounds very similar to the case that led to "Solange I":

"As long as the European Communities, in particular European Court case law, generally ensure effective protection of fundamental rights as against the sovereign powers of the Communities which is to be regarded as substantially similar to the protection of fundamental rights required unconditionally by the Constitution, and in so far as they generally safeguard the essential content of fundamental rights, the Federal Constitutional Court will no longer exercise its jurisdiction to decide on the applicability of secondary Community legislation cited as the legal basis for any acts of German courts or authorities within the

${ }^{6}$ Cf. BVerfGE 58, 1 (EUROCONTROL); see also BVerfGE 52, 187. 
sovereign jurisdiction of the Federal Republic of Germany, and it will no longer review such legislation by the standard of the fundamental rights contained in the Basic Law; references to the Court under Article 100.1 of the Basic Law for those purpose are therefore inadmissible". 7

The Court, after reminding the "Solange I" decision, explained its 180 degrees turnaround by saying:

"In the judgment of this Chamber a measure of protection of fundamental rights has been established in the meantime within the sovereign jurisdiction of the European Communities which in its conception, substance and manner of implementation is essentially comparable with the standards of fundamental rights provided for in the Basic Law. All the main institutions of the Community have since acknowledged in a legally significant manner that in the exercise of their powers and the pursuit of the objectives of the Community they will be guided as a legal duty by respect for fundamental rights, in particular as established by the constitutions of member states and by the European Convention on Human Rights. There are no decisive factors to lead one to conclude that the standard of fundamental rights which has been achieved under Community law is not adequately consolidated and is only of a transitory nature (...). The European Court has generally recognised and consistently applied in its decision the principles, which follow from the rule of law, of the prohibition of excessive action and of proportionality as general legal principles in reaching a balance between the common interest objectives of the Community legal system and the safeguarding of the essential content of fundamental rights (...)".

One might add that the ECJ might have misunderstood in the years after and until today the Constitutional Court's formula as to "the safeguarding of the essential content of fundamental rights". ${ }^{8}$ When scrutinising a Community measure, the ECJ limits itself to check whether the measure is suitable to achieve its goal, and whether it does not infringe upon the essential content of a human right. In the German doctrine, the "essential content" is the lowest limit of protection; Article 19 section 2 of the Basic Law states: "In no case may the essence of a basic right be affected". The regular level of protection is much higher: suitability, necessity (principle of mildest means) and proportionality. ${ }^{9}$

The "Solange II" formula of the German Constitutional Court has, by the way, also been adopted by the European Court of Human Rights (ECHR), ${ }^{10}$ although with one difference: whilst the German Constitutional Court will exercise its reserved competence to control Community acts under the aspect of human rights only in case that the ECJ will fail in a general manner to ensure effective protection of fundamental rights ("substantial decrease in the standard of human rights protection"), the ECHR reserves that competence also in case of insufficient protection in an isolated case. ${ }^{11}$

\footnotetext{
${ }^{7}$ BVerfGE 73, 339.

${ }^{8}$ Stein [7], p. 1431.

${ }^{9}$ Cf. Singh [5], p. 163 et seq.

${ }^{10}$ ECHR, 30.6.2005, Application No. 45036/98 (Bosphorus).

${ }^{11}$ Grabenwarter [3], p. 119 et seq.
} 


\section{The European Union}

In the context of the establishment of the European Union under the Maastricht Treaty the German Constitutional Court extended its theoretical control over European legislative acts. Had it hitherto only been the protection of human rights, the Court now took into its focus also democracy, representation and legitimisation as well as constitutional principles and fundamental interests of the Member States.

\subsection{The Maastricht Decision}

In its decision on the Maastricht Treaty of 12 October $1993^{12}$ the Constitutional Court in essence repeated its earlier decisions on the protection of human rights, stating that the Federal Constitutional Court exercises its jurisdiction over the applicability of secondary Community Law in Germany in a "relationship of cooperation" with the European Court of Justice. In this relationship, the European Court of Justice guarantees the fundamental rights protection in each individual case for the whole area of the European Community, and the Federal Constitutional Court can therefore limit itself to the general guarantee of the indispensable fundamental rights standard". Some rightly pointed out that this "relationship of cooperation" rather looked like "final control" by the Constitutional Court. ${ }^{13}$

The Court then went on to qualify the European Union as an "association of democratic states" ("Staatenverbund"), states which remained sovereign. The principle of democracy requires, so the Court, that the execution of sovereign powers must derive from "the people of the State". This does not exclude membership in a community of states authorised to issue sovereign acts, but that authority is limited to those sovereign rights transferred by the national parliament under the law giving assent to the Maastricht Treaty. Any act not covered by that law, and thus transgressing the limits of the transfer ("ausbrechender Rechtsakt") would not be valid and applicable in Germany. The Court thus (theoretically) refused to recognise the primacy of Community law and the ECJ's prerogative to delimit the competences of the Community in a given case. Strong words, but nothing followed. Some had expected that the Constitutional Court would at least indicate that it was not amused by the standard of human rights protection offered by the ECJ in its Banana Market organisation judgments, but in its own decision ${ }^{14}$ in this case the Constitutional Court simply repeated the "Solange II" formula and declared the complaint as inadmissible.

\subsection{The Lisbon Decision}

Words became even stronger in the Constitutional Court's decision on the Lisbon Treaty. Suffice it to recall the headnotes: ${ }^{15}$

\footnotetext{
${ }^{12}$ BVerfGE 89, 155.

${ }^{13}$ Herdegen [4], p. 252.

${ }^{14}$ BVerfGE 102, 147.

${ }^{15}$ BVerfGE 123, 267.
} 
"Article 23 of the Basic Law grants powers to take part in and develop a European Union designed as an association of sovereign states ("Staatenverbund"). The concept of Verbund covers a close long-term association of states which remain sovereign, a treaty-based association which exercises public authority, but whose fundamental order is subject to the decision-making power of the Member States and in which the peoples, i.e. the citizens, of the Member States remain the subjects of democratic legitimation.

In so far as the Member States elaborate treaty law in such a way as to allow treaty amendment without a ratification procedure, whilst preserving the application of the principle of conferral, a special responsibility is incumbent on the legislative bodies, in addition to the Federal Government, within the context of participation which in Germany has to comply internally with the requirements under Article 23.1 of the Basic Law (responsibility for integration) and which may be invoked in any proceedings before the Federal Constitutional Court. European unification on the basis of a treaty union of sovereign states may not be achieved in such a way that not sufficient space is left to the Member States for the political formation of economic, cultural and social living conditions. This applies in particular to areas which shape the citizens' living conditions, in particular the private sphere of their own responsibility and of political and social security, protected by fundamental rights, as well as to political decisions that rely especially on cultural, historical and linguistic perceptions and which develop within public discourse in the party political and parliamentary sphere of public politics.

The Federal Constitutional Court examines whether legal instruments of the European institutions and bodies keep within the boundaries of the sovereign powers accorded to them by way of conferral, whilst adhering to the principle of subsidiarity under Community and Union law (Article 5.1 second sentence and 5.3 of the Treaty on European Union in the version of the Treaty of Lisbon). Furthermore, the Federal Constitutional Court reviews whether the inviolable core content of the constitutional identity of the Basic Law pursuant to Article 23.1 third sentence in conjunction with Article 79.3 of the Basic Law is respected. The exercise of this review power, which is rooted in constitutional law, follows the principle of the Basic Law's openness towards European Law ("Europarechtsfreundlichkeit"), and it therefore also does not contradict the principle of sincere cooperation (Article 4.3 Lisbon TEU); otherwise, with progressing integration, the fundamental political and constitutional structures of sovereign Member States, which are recognised by Article 4.2 first sentence Lisbon TEU, cannot be safeguarded in any other way. In this respect, the guarantee of national constitutional identity under constitutional and under Union law go hand in hand in the European legal area."

Quite a few severely criticised the Lisbon decision as returning to a strictly nationalistic view and as damaging the integration process. ${ }^{16}$ Others asked themselves whether

${ }^{16}$ Cf. Zeitschrift für Europarechtliche Studien [8], pp. 491-729. 
this time action would follow the words, and already had a suitable case in mind, the Mangold judgment of the ECJ. ${ }^{17}$

\section{The Mangold Judgment of the ECJ}

The case relates to a fixed-term employment contract, signed on 26 June 2003, between Mr. Mangold, then 56 years old, and his employer, a practising lawyer. Under the German labour law in force at this time, fixed-term contracts could be concluded if there were objective grounds for doing so. An exception (no objective reasons necessary) applied to workers having reached the age of 52. With this exception, the German legislator was pursuing the goal of reducing the statistically much higher unemployment among older people by lowering the barriers for their re-entry into working life.

Apparently in agreement with his employer, Mr. Mangold challenged the limitation of his contract before the Munich Labour Court, which in turn referred the case to the ECJ, asking whether it had to refuse to apply the provisions of domestic law in view of Community law prohibiting discrimination on the grounds of, inter alia, age. The primarily relevant norm on the Community level was Directive 2000/78/EC of 27 November $2000,{ }^{18}$ which, however, had to be transposed by Germany only until 2 December 2006. The ECJ, nevertheless, confirmed that the legitimacy of the public-interest objective pursued by the German legislation was in line with Article 6 of the Directive and could not reasonably be thrown in doubt.

But the ECJ then goes on to ask whether the means used to achieve that legitimate object were "appropriate and necessary"; the answer is remarkable: It is not the Directive itself that lays down the principle of non-discrimination on grounds of age, but it is "a general principle of Community law" that could be found "in various international instruments and in the constitutional traditions common to the Member States". The ECJ does not name only one example for those instruments and constitutional traditions, but refers to the third and fourth recitals in the preamble of the Directive. And a look at these recitals reveals that the third only refers to Article 3 (2) of the (then) EC-Treaty and in particular to the discrimination of women. The fourth recital simply lists all international human rights conventions to which all Member States are signatories. All these international instruments do contain a provision on the equality of all persons before the law and equal protection without any discrimination of the law, but none mentions discrimination on grounds of age. The same is true for the "constitutional traditions common to the Member States". Only the Finnish Constitution (Article 6) and - if at all - the Portuguese Constitution (Article 59) contain such a provision. ${ }^{19}$ That is by no means enough for a "common tradition".

In Mangold the ECJ had at best anticipated, but in reality invented a new fundamental right (general principle of Community law), and had ordered a national court

\footnotetext{
${ }^{17}$ Case C-144/04 Mangold [2005] ECR I-9981.

${ }^{18}$ Council Directive 2000/78/EC of 27 November 2000 establishing a general framework for equal treatment in employment and occupation, OJ L 303 of 2 December 2000, p. 16.

${ }^{19}$ Gerken and others [2], p.19 et seq.
} 
to disregard a national legal provision which was, at the time, otherwise not in conflict with Community law. ${ }^{20}$ One might argue that the ECJ's decision was to the benefit of an elderly worker, but it was also to the detriment of an employer having trusted in the national statutory provision and having made plans on this trust. The ECJ did not address the question of good faith or legitimate expectations in Mangold, perhaps because it was evident that this was a case deliberately fabricated by the employee and the employer, but the Court should have considered that its dictum would also apply to cases in which the employer had trusted in the validity of the national legislation. An example for that was the Honeywell case, and quite a few ${ }^{21}$ who considered Mangold to be an ultra vires act in the sense of the Maastricht and Lisbon decisions of the German Federal Constitutional Court, expected the Constitutional Court to at least show the ECJ a "yellow card".

\section{The Honeywell Decision of the German Federal Constitutional Court}

The facts in Honeywell were almost identical with those in Mangold, the only differences being that it was not "fabricated" and was not referred to the ECJ, although it could and should have been. The employer in question had concluded in 2003 thirteen fixed-term contracts with employees over 52 years of age, previously unemployed, in order to cover production peaks. One of them challenged the limitation of his contract, lost in two instances and finally filed an appeal with the Federal Labour Court. That Court squashed the previous rulings of the lower labour courts and the limitation of the contract, basing itself on the ECJ's Mangold ruling. That ruling, it was said, was absolutely clear, so that there was no need for a renewed referral to the ECJ. The company Honeywell filed a constitutional complaint against this judgment with the Federal Constitutional Court.

And the answer of the Constitutional Court? ${ }^{22}$ The Court, with the exception of one dissenting judge, seemed to have completely forgotten or abandoned its strong words in the Maastricht and Lisbon decisions. Suffice it again to see the official headnotes in the English version published by the Court:

"Ultra vires review by the Federal Constitutional Court can only be considered if a breach of competences on the part of the European bodies is sufficiently qualified. This is contingent on the act of the authority of the European Union being manifestly in breach of competences and the impugned act leading to a structurally significant shift to the detriment of the Member States in the structure of competences.

Prior to the acceptance of an ultra vires act, the Court of Justice of the European Union is to be afforded the opportunity to interpret the Treaties, as well as to rule on the validity and interpretation of the acts in question, in the context of

\footnotetext{
${ }^{20}$ Not only Directive 2000/78, but also the Charter of Fundamental Rights of the European Union (and its Article 21) were not binding on Germany at the time.

${ }^{21}$ Gerken and others [2], passim.

${ }^{22}$ Case 2 BVR 2661/06, Decision of 6 July 2010, NJW 2010, 3422.
} 
preliminary ruling proceedings according to Article 267 TFEU, insofar as it has not yet clarified the questions which have arisen.

To ensure the constitutional protection of legitimate expectations, it should be considered, in constellations of retroactive inapplicability of a law as a result of a ruling by the Court of Justice of the European Union, to grant compensation domestically for a party concerned having trusted in the statutory provision and having made plans based on this trust.

Not all violations of the obligation under Union law to make a submission constitute a breach of Article 101.1 sentence 2 of the Basic Law. The Federal Constitutional Court only complains of the interpretation and application of rules on competences if, on a sensible evaluation of the concepts underlying the Basis Law, they no longer appear to be comprehensible and are manifestly untenable. This standard for what is considered arbitrary is also applied if a violation of Article 267.3 TFEU is considered to have taken place."

The threshold for an ultra vires review is now so high that the ECJ will most probably never cross it. "Mission creep" is more likely than a "coup d'état" leading to a structurally significant shift to the detriment of the Member States in the structure of competences. And "sufficiently qualified" is the same vague term the ECJ is using when regularly dismissing claims for non-contractual liability of the European Union (Article 340 section 2 TFEU). And what does it mean if the Court says that "prior to the acceptance (sic!) of an ultra vires act, the ECJ is to be afforded the opportunity to ... rule on the validity and interpretation of the acts in question ..."? Is the Constitutional Court now prepared to refer a question for a preliminary ruling to the ECJ, which it has until now fiercely refused? Not very likely if one reads how generous the Court is with the fact that the Federal Labour Court did not refer Honeywell to the ECJ. The "domestic compensation" is at best lex desiderata. The existing rules on state liability in Germany require an illegal act of an organ of the State and do not include a "legislative wrong". And how could the legislator or a court, when applying a national statute, "predict" that the ECJ might one day classify such a provision as being in violation of Union law?

\section{Conclusion}

One wonders what has induced the Federal Constitutional Court to that complete and undeniable turn backward after Maastricht and Lisbon. It is rumoured that the Court was under strong political pressure. The reporting judge, who was also reporting in Lisbon, shortly after the Honeywell decision tried to explain the decision in a nation-wide daily paper, speaking of self-restraint and of consideration. ${ }^{23}$ Many will certainly praise the Constitutional Court for returning to its original "integrationfriendly" position. But the Court could have done better: why did it not send the case back to the Federal Labour Court, demanding a reference to the ECJ under Article 101 of the German Constitution, asking the ECJ whether not only the prohibition

${ }^{23}$ Di Fabio [1], p. 6. 
of discrimination on grounds of age is a general principle of union law, but also the protection of legitimate expectations? This would have avoided a clash between the Constitutional Court and the ECJ, but would at the same time have made it clear that the Constitutional Court takes its "reserved competence" serious. Why bark and not bite? All the ECJ now sees is the white flag over Karlsruhe. ${ }^{24}$

\section{References}

1. Di Fabio, U.: Friedliche Koexistenz (peaceful coexistence). Frankfurter Allgemeine Zeitung, 21 October 2010

2. Gerken, L., et al.: "Mangold" als ausbrechender Rechtsakt. Sellier, München (2009)

3. Grabenwarter, Ch.: Europäische Menschenrechtskonvention, 4th edn. Beck, München (2009)

4. Herdegen, M.: Europarecht, 12th edn. Beck, München (2010)

5. Singh, M.P.: German Administrative Law in Common Law Perspective, 2nd edn. Springer, Berlin (2001)

6. Stein, T.: Arrivederci Karlsruhe. Zeitschrift für Rechtspolitik 8/2010, 265

7. Stein, T.: "Gut gemeint" - Bemerkungen zur Charta der Grundrechte der Europäischen Union. In: Festschrift für Helmut Steinberger, p. 1425. Springer, Berlin (2002)

8. Zeitschrift für Europarechtliche Studien (ZEuS): Special edn., vol. 12(4) (2009)

${ }^{24}$ Cf. Stein [6], p. 265. 